\title{
Monitoring Enzyme Synthesis as a Means of Studying Peptide Transport and Utilization in Escherichia coli
}

\author{
By G. BELL, G. M. PAYNE AND J. W. PAYNE \\ Department of Botany, University of Durham, Science Laboratories, \\ South Road, Durham DHI $3 L E$
}

(Received 26 July 1976; revised 10 September 1976)

\begin{abstract}
SUMM AR Y
A new method has been developed for measuring peptide transport in aminoacid auxotrophs of Escherichia coli by following induction of $\beta$-galactosidase. Appearance of the enzyme was determined after addition of inducer and peptides to amino-acid starved bacteria. For a given number of lysine equivalents, the rate and the extent of enzyme synthesis were the same for lysine and lysyl peptides; similar results were found for glycine and glycyl peptides. Saturation constants for peptide transport were determined from the exogenous peptide concentration that gave half maximal rates of enzyme synthesis. The saturation constants, studies with mutants defective in peptide transport, and detection of competition between peptides for uptake, all endorsed earlier conclusions from growth tests about the structural specificities for peptide transport. The new method is quicker, more sensitive and more informative than growth tests.
\end{abstract}

\section{INTRODUCTION}

Peptide transport in Escherichia coli occurs by permeases which are specific for di- or oligopeptides. After uptake, peptides are hydrolysed by intracellular peptidases and then incorporated into protein. Because of the difficulty in obtaining radioactive peptides, the present picture of peptide transport and utilization has been obtained mainly from studies of the growth responses of amino-acid auxotrophs to peptides, and of the effects of inhibitory peptides on the growth of wild-type strains (e.g. Barak \& Gilvarg, 1975a; Payne, 1975, 1976; Payne \& Gilvarg, 197I; Simmonds, 1972; Sussman \& Gilvarg, 197I). There are several limitations to these methods: they require fairly large quantities of peptide and long incubations (e.g. $8 \mathrm{~h}$ ), and measurement of growth by following turbidity is relatively insensitive. The present paper describes a method which is faster, and more sensitive and informative. Amino-acid auxotrophs are used, but instead of measuring growth, the peptide-dependent synthesis of $\beta$-galactosidase (EC. 3.2.I.23) is measured.

\section{METHODS}

Materials. Lysine peptides were synthesized as described previously (Payne, 1968). Amino acids and glycyl peptides were obtained from BDH. Isopropyl- $\beta$-D-thiogalactopyranoside and $o$-nitrophenyl- $\beta$-D-galactopyranoside were purchased from Sigma.

Growth of bacteria and $\beta$-galactosidase assav. All strains were derived from Escherichia coli W ATCC9637. The lysine auxotroph (M-26-26), the glycine/serine auxotroph (M-123) and their respective oligopeptide permease-deficient mutants $\mathrm{M}-26-26$. TOR and $\mathrm{M}-\mathrm{I} 23$. TOR 
have been described previously (Payne, 1968, I974). Cultures (75 to I00 $\mathrm{ml}$ ) were shaken at $\mathrm{I} 60$ strokes $\mathrm{min}^{-1}$ in a water bath (Grant Instruments, Cambridge) at $37^{\circ} \mathrm{C}$; each flask $(250 \mathrm{ml})$ was fitted with a side-arm so that growth could be measured at $660 \mathrm{~nm}$ in a Bausch \& Lomb Spectronic 20. The minimal medium A of Davis \& Mingioli (1950) was used but, to prevent catabolite repression, citrate was omitted and sodium lactate $(0.6 \%, \mathrm{w} / \mathrm{v}$; prepared by neutralizing lactic acid with $\mathrm{NaOH}$ ) was used as carbon source. Growth was limited by lysine $(0.05 \mathrm{~mm})$ or glycine $(0.5 \mathrm{~mm})$ to an absorbance of about 0.5 at $660 \mathrm{~nm}$ (about $5 \times 10^{8}$ bacteria $\mathrm{ml}^{-1}$ ). Incubation of the bacteria was continued for $\mathrm{I}$ to $2 \mathrm{~h}$ after cessation of growth in order to ensure adequate depletion of the appropriate amino acid. The bacteria were collected by centrifuging at about $8000 \mathrm{~g}$ for Io $\mathrm{min}$, and then resuspended to about $2 \times 10^{8}$ bacteria $\mathrm{ml}^{-1}$ in fresh minimal medium (approx. $100 \mathrm{ml}$ ) equilibrated at $37^{\circ} \mathrm{C}$ and containing I mM-isopropyl- $\beta$-D-thiogalactopyranoside as inducer. This suspension was equilibrated with shaking under the conditions described above for 30 to $40 \mathrm{~min}$. Portions $(8.0 \mathrm{ml})$ of the suspension were then added to aqueous solutions $\left(2.0 \mathrm{ml} ; 37^{\circ} \mathrm{C}\right)$ of appropriate amino acids or peptides in tubes $(2 \times 15 \mathrm{~cm})$ and incubated at $37^{\circ} \mathrm{C}$ in a water bath with shaking (200 strokes $\left.\mathrm{min}^{-1}\right)$. Samples $(0.5 \mathrm{ml})$ were removed periodically into test tubes $(\mathrm{I} \times 10 \mathrm{~cm})$ containing toluene $(50 \mu \mathrm{l})$, mixed on a vortex mixer for $30 \mathrm{~s}$ and then incubated for $20 \mathrm{~min}$ at $37^{\circ} \mathrm{C}$ in a water bath without shaking. One $\mathrm{ml}$ of $5 \mathrm{mM}-$ $o$-nitrophenyl- $\beta$-D-galactopyranoside, pre-equilibrated at $37^{\circ} \mathrm{C}$, was added and the solutions were incubated in a water bath at $37^{\circ} \mathrm{C}$ without shaking for 20 to $60 \mathrm{~min}$ as convenient; enzyme action was then stopped by adding $0.2 \mathrm{ml} \mathrm{I} \mathrm{mM-Na} \mathrm{CO}_{3}$. The extent of $\beta$-galactosidase synthesis is proportional to the amount of $o$-nitrophenol released; this was measured at $420 \mathrm{~nm}$ in a Gilford model 2000 spectrophotometer using $\mathrm{I} \mathrm{cm}$ pathlength cuvettes. Under these conditions an $E_{420}$ of I is equivalent to $0.23 \mu \mathrm{mol} o$-nitrophenol formed per $\mathrm{ml}$ of incubation mixture.

\section{RESULTS}

In preliminary studies, bacteria were harvested in the exponential phase of growth, resuspended in fresh growth medium but without the required amino acid, and incubated for about $40 \mathrm{~min}$ at $37^{\circ} \mathrm{C}$ to use up any residual amino acid before inducing $\beta$-galactosidase. However, this procedure gave variable, and occasionally unacceptably high, 'blank' or 'zero time' amounts of $\beta$-galactosidase. Subsequent use of amino-acid starved cells, as described in Methods, overcame this difficulty and still gave rapid initiation of enzyme synthesis.

\section{Transport and utilization of lysyl and glycyl peptides}

The ability of the lysine auxotroph M-26-26 to transport and to utilize di-, tri-, and tetralysine is shown by the capacity of these peptides to support $\beta$-galactosidase synthesis in bacteria starved of lysine (Fig. I). In this experiment, enzyme synthesis was detected within ro min of supplying each lysine source. Absorbances at zero time are mainly non-specific; they are caused by suspended bacteria and low basal activities of $\beta$-galactosidase. The same rate of enzyme synthesis was observed with lysine and with each of the lysine peptides, indicating that the uptake and the hydrolysis of these di- and oligopeptides [which occur by distinct permeases (Payne, 1968, 1975, 1976; Payne \& Gilvarg, 197I) and by separate peptidases (Sussman \& Gilvarg, 1970, 1971) respectively] are both extremely rapid processes and neither is rate limiting for protein synthesis. Additionally, the final plateaux of enzyme activity indicate that the same amounts of $\beta$-galactosidase are synthesized from given amounts of lysine, whether it is provided as the free amino acid or in a peptide. Analogous 


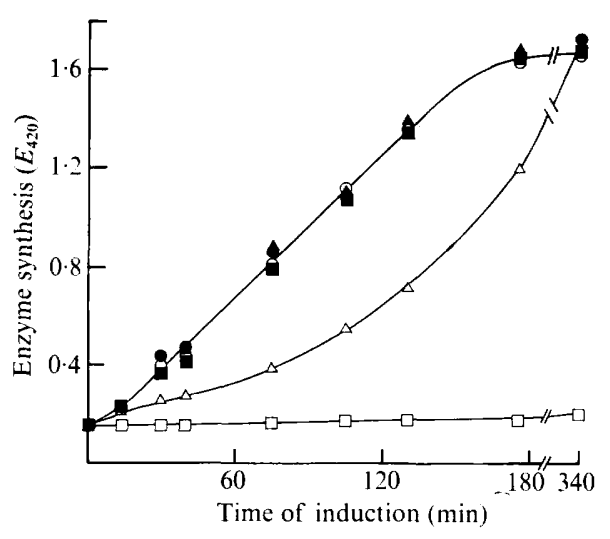

Fig. I

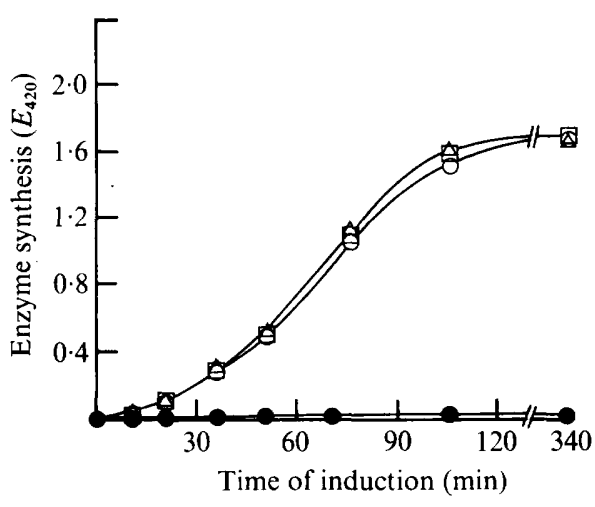

Fig. 2

Fig. I. Transport and utilization of lysine and lysine peptides by $E$. coli lysine auxotroph $M-26-26$ monitored by $\beta$-galactosidase synthesis. Bacteria were used at $E_{660}=0.14$ in the induction medium, and formation of $o$-nitrophenol was measured at $420 \mathrm{~nm}$ after $20 \mathrm{~min}$ enzyme action. The following additions were made at zero time: $15 \mu \mathrm{M}$-lysine $(\boldsymbol{\Delta}) ; 7.5 \mu \mathrm{M}$-dilysine $(\boldsymbol{O}) ; 5 \mu \mathrm{M}$-trilysine ( $\boldsymbol{\square})$; 3.75 $\mu \mathrm{M}$-tetralysine ( $\bigcirc$ ); I $5 \mu \mathrm{M}$-lysine plus $4 \mu \mathrm{M}$-triornithine $(\triangle)$; control, no lysine source ( $\square$ ).

Fig. 2. Transport and utilization of glycine and glycyl peptides by $E$. coli glycine auxotroph $\mathrm{M}-\mathrm{I} 23$ monitored by $\beta$-galactosidase synthesis. Bacteria were used at $E_{660}=0.14$ in the induction medium, and formation of $o$-nitrophenol was measured at $420 \mathrm{~nm}$ after $30 \mathrm{~min}$ enzyme action. The following additions were made at zero time: $100 \mu \mathrm{M}$-glycine $(\triangle) ; 50 \mu \mathrm{M}$-diglycine ( $\square$ ); $33 \mu \mathrm{M}$-triglycine $(\bigcirc)$; control, no glycine source (O).

curves were obtained using different concentrations of bacteria $\left(E_{660}=0.05\right.$ to 0.7$)$; the rates of enzyme synthesis were proportional to the numbers of cells but the amount of $\beta$-galactosidase synthesized was determined solely by the amount of lysine added. The inhibitory effect of triornithine on protein synthesis (Gilvarg \& Levin, 1972; Barak, Sarid \& Katchalski, 1973) is also shown (Fig. I) but the high concentration of E. coli apparently quickly hydrolysed the tripeptide and destroyed its inhibitory properties.

Use of the new method was further validated by results for the transport and utilization of glycine, di-, tri-, and tetraglycine by the glycine auxotroph M-I23 (Fig. 2). Similar rates of enzyme synthesis occurred with each glycine source; tetraglycine gave the same results as diglycine but is omitted for clarity. Yields of $\beta$-galactosidase were the same for a given amount of free or peptide-bound glycine. However, the yield of $\beta$-galactosidase obtained with glycine was only about one-tenth that obtained with the same molarity of lysine, but rather than make the enzyme assay period unduly long, we chose to increase the concentrations of glycine used so that more $\beta$-galactosidase would be synthesized and the routine 20 to $30 \mathrm{~min}$ incubation time maintained.

\section{Use of peptide permease mutants}

In earlier growth studies, mutants defective in peptide transport have been used to establish structural specificities of peptide permeases of E. coli (Payne, 1968, 1975, 1976; Payne \& Gilvarg, I97I; Barak \& Gilvarg, I975a). Results using our new method were similar to those obtained in earlier work. The oligopeptide transport mutant M-I23. TOR transported and utilized glycine and diglycine for the synthesis of $\beta$-galactosidase (Fig. $3 a$ ) as did the parent strain (Fig. 2), but failed to utilize tri- and tetraglycine. Similarly, the oligopeptide permease mutant M-26-26.TOR of the lysine auxotroph transported and utilized dilysine (Fig. $3 b$ ) but not the oligopeptides trilysine or tetralysine (not shown in 


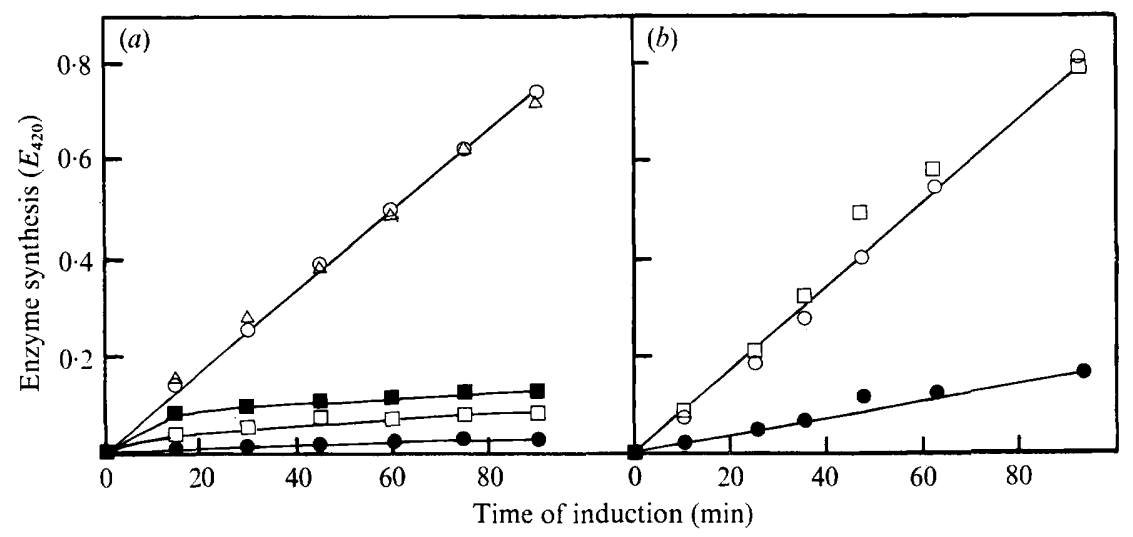

Fig. 3. Transport and utilization of peptides by mutants of $E$. coli defective in the oligopeptide permease monitored by $\beta$-galactosidase synthesis. (a) Glycine auxotroph M-I 23.TOR was used at $E_{660}=0.3$ in the induction medium, and formation of $o$-nitrophenol was measured at $420 \mathrm{~nm}$ after $20 \mathrm{~min}$ enzyme action. The following additions were made at zero time: I $50 \mu \mathrm{M}$-glycine $(\mathrm{O}) ; 75 \mu \mathrm{M}-$

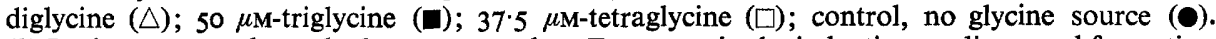
(b) Lysine auxotroph M-26-26.TOR was used at $E_{660}=0.2$ in the induction medium, and formation of $o$-nitrophenol was measured at $420 \mathrm{~nm}$ after $20 \mathrm{~min}$ enzyme action. The following additions were made at zero time: $15 \mu \mathrm{M}$-lysine ( $\square) ; 7.5 \mu \mathrm{M}$-dilysine (O); $5 \mu \mathrm{M}$-trilysine (๑).

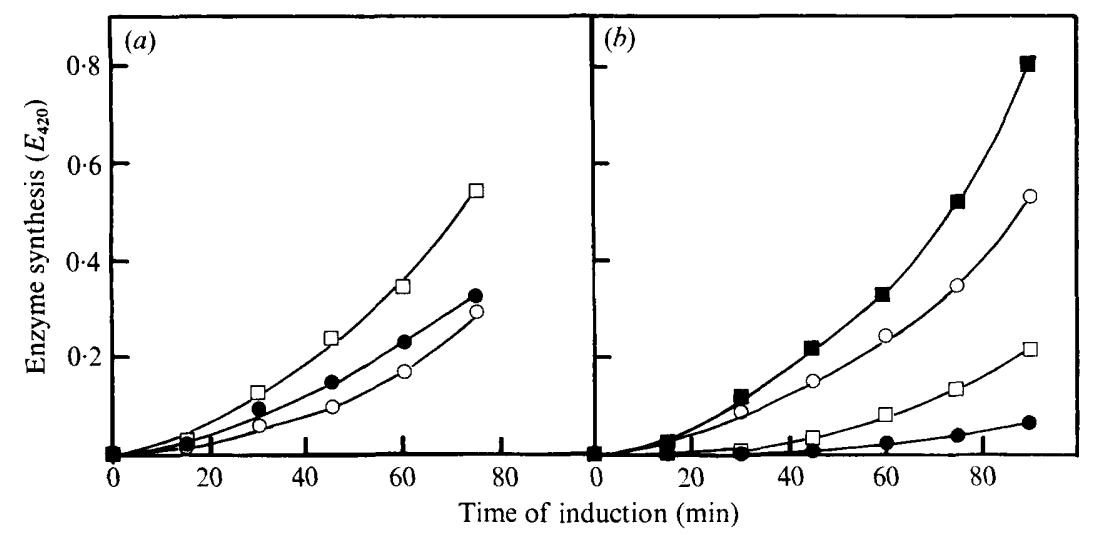

Fig. 4. Competition between dipeptides and oligopeptides for transport by $E$. coli glycine auxotroph M-123 monitored by $\beta$-galactosidase synthesis. Bacteria were used at $E_{660}=0.3$ in the induction medium, and formation of $o$-nitrophenol was measured at $420 \mathrm{~nm}$ after $20 \mathrm{~min}$ enzyme action. The following additions were made at zero time: (a) $33 \mu \mathrm{M}$-triglycine ( $\square$ ); $33 \mu \mathrm{M}$-triglycine

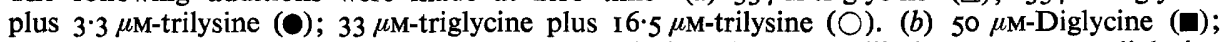
$50 \mu \mathrm{M}$-diglycine plus $2 \mu \mathrm{M}$-dilysine $(\bigcirc) ; 50 \mu \mathrm{M}$-diglycine plus $10 \mu \mathrm{M}$-dilysine ( $\square$ ); $50 \mu \mathrm{M}$-diglycine plus $50 \mu \mathrm{M}$-dilysine (๑).

Fig. $3 b$ ). Both these mutants showed undiminished rates of enzyme synthesis in the presence of $4 \mu \mathrm{M}$-triornithine which inhibited enzyme synthesis in the parent strain (Fig. I). Enzyme synthesis observed with some oligopeptides (Fig. 3) may arise from (i) contamination by lower homologues; (ii) protein turnover; (iii) cleavage by periplasmic amino-endopeptidase activity (Lazdunski, Basuttil \& Lazdunski, 1975); (iv) uptake by diffusion and/or specialized transport systems (Payne, I968; Cowell, 1974; Naider \& Becker, 1975; Barak \& Gilvarg, $1975 b$ ). The present procedure is a much more sensitive way of assessing possible contributions from (iii) and (iv) than the usual growth studies. 


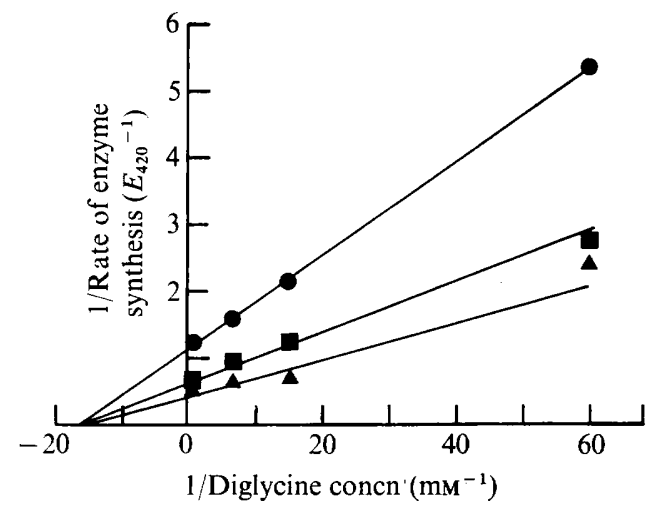

Fig. 5. Determination of saturation constants for transport of diglycine by E. coli glycine auxotroph M-I 23. Bacteria were used at $E_{660}=0 \cdot I$ in the induction medium, and formation of $o$-nitrophenol was measured at $420 \mathrm{~nm}$ after 60 min enzyme action. The amount of $\beta$-galactosidase formed was determined after $30 \mathrm{~min}(\boldsymbol{\bullet}), 45 \mathrm{~min}(\boldsymbol{\square})$, and $60 \mathrm{~min}(\boldsymbol{\Lambda})$ biosynthesis.

\section{Competition during peptide transport}

Use of the new method was further endorsed by results on competition in agreement with earlier studies on effects on growth (Payne, 1968, 1975, I976; Payne \& Gilvarg, 197I ; Barak \& Gilvarg, 1975a). Thus, dilysine inhibited diglycine transport via the dipeptide permease (Fig. $4 b$ ), and trilysine competed with triglycine for uptake by the oligopeptide permease (Fig. $4 a$ ) making the supply of glycine rate limiting for enzyme synthesis in strain M-I23. With the new approach, competition can be assessed within minutes, and peptides can be used at low concentrations.

\section{Affinities of peptides for transport systems}

Some measure of the relative affinities of peptides for their permeases can be obtained from their competitive abilities. However, a more direct measure of the affinity of a peptide for the transport system is obtained from measurement of the rate of enzyme synthesis as a function of peptide concentration. Results of an experiment using diglycine are shown as a double reciprocal plot (Fig. 5), with the intercept on the abscissa giving an affinity constant for transport of $6.3 \times 10^{-5} \mathrm{M}$; i.e. the concentration that supports half maximal rate of $\beta$-galactosidase synthesis. In other experiments the following affinity constants were determined (ranges from four to six experiments): triglycine $4.0 \pm 0.8 \times 10^{-4} \mathrm{M}$; trilysine $3.9 \pm 0.4 \times 10^{-7} \mathrm{M}$; dilysine $3.4 \pm 0.5 \times 10^{-7} \mathrm{M}$. These values accord with the relative competitive abilities of the glycine and lysine peptides (see rest of text, and Payne, 1968). Providing intracellular hydrolysis was not rate limiting, the procedure could be used to determine affinity constants for the transport of any peptide.

\section{DISCUSSION}

The fact that glycyl and lysyl peptides were shown by the new method to be utilized for enzyme synthesis by the starved auxotrophs only a few minutes after addition (Figs I and 2) provides convincing evidence for the constitutive nature of the peptide permeases and also for the presence of active, constitutive peptidases (the bacteria had been grown without peptides in the medium) (Sussman \& Gilvarg, I971; Simmonds, 1970, 1972). 
In determining permease affinity from the exogenous peptide concentration that makes peptide transport (and hence intracellular supply of required amino acid) become just limiting fer enzyme synthesis in an auxotroph (Fig. 5), the approach is somewhat similar to that of Ames (1964) for finding 'limit concentration' values. An assumption of our approach is that uptake and not hydrolysis is the rate-limiting step. Pertinent to this assumption and to the method in general are the following calculations. At the cell concentration used in a typical assay $\left(E_{660}=0.15 ; 2 \times 10^{8}\right.$ bacteria $\left.\mathrm{ml}^{-1}\right)$, the dry weight of bacteria is about $0.05 \mathrm{mg} \mathrm{ml}^{-1}$, of which about $50 \%$ is protein. For, say, diglycine (Fig. 2), $50 \mathrm{nmol}$ is completely utilized (and therefore necessarily hydrolysed) in $100 \mathrm{~min}$. Thus, the minimum specific activity for 'diglycine peptidase(s)' in vivo under these experimental conditions is about $20 \mathrm{nmol}$ peptide cleaved $\min ^{-1}\left(\mathrm{mg}\right.$ protein) ${ }^{-1}$ and, similarly, for triglycine (Fig. 2) about $15 \mathrm{nmol} \mathrm{min}^{-1}$ (mg protein) $)^{-1}$, and for di- and trilysine (Fig. I)

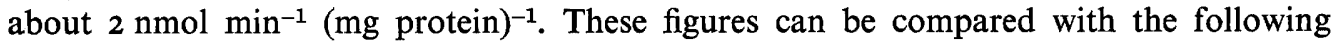
values measured in vitro using crude extracts of several strains of $E$. coli: di- and triglycine,

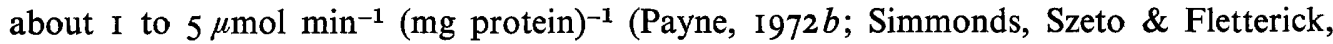
I976; Patterson, Gatmaitan \& Hayman, 1975); di- and trilysine, about 2.25 and $0.25 \mu \mathrm{mol}$ $\min ^{-1}$ (mg protein) ${ }^{-1}$ respectively (Sussman \& Gilvarg, 1970; Simmonds et al., 1976). When comparing calculated activities in vivo with observed activities in vitro due attention must be given to the substrate concentration at which the peptidases are acting. For example, for the enzyme that cleaves diglycine, a $K_{\mathrm{m}}$ value in vitro of about $2 \mathrm{~mm}$ has been determined (Payne, 1972 a; Hayman, Gatmaitan \& Patterson, 1974). In the present method, diglycine was used at about $0.05 \mathrm{~mm}$ (Fig. 2), requiring it to be accumulated 40 -fold over its concentration in the medium for the intracellular peptidase to work at half maximal velocity in vivo. This level of accumulation is not unusual and has been reported for diglycine (Kessel \& Lubin, I963).

We chose to monitor $\beta$-galactosidase synthesis because it is well characterized and easily assayed. Putnam \& Koch (1975) recently described an improved assay. The sensitivity of the procedure could be increased by extending the time the enzyme acts on its substrate Other inducible or derepressible enzymes could be used to monitor peptide transport and utilization, and with alkaline phosphatase we have obtained similar results to those described here. Cascieri \& Mallette (I974) have described a related method in which wild-type bacteria were put into a state of 'physiological auxotrophy' by shifting from a medium containing methionine (to repress methionine biosynthetic enzymes) to one without methionine; synthesis of induced lysine decarboxylase in these cells was then shown to be dependent for a limited period on added methionine or methionine peptide. Their procedure was too involved for routine study of peptide transport. Furthermore, it cannot be used to assess peptide utilizability based on enzyme yield because physiological auxotrophy is too quickly lost. However, their approach offers a way of investigating peptidase activities in vivo under different physiological conditions from those present in the starved auxotrophs used here.

We are grateful for the financial support provided by the Science Research Council, The Royal Society, and Smith, Kline and French Foundation. 


\section{REFERENCES}

Ames, G. F. (1964). Uptake of amino acids by Salmonella typhimurium. Archives of Biochemistry and Biophysics 104, I-18.

BaraK, Z. \& GILVARG, C. (I975a). Peptide transport. In Biomembranes, vol. 7, pp. 167-218. Edited by H. Eisenberg, E. Katchalski-Katzir and L. A. Manson. New York: Plenum Press.

Barak, Z. \& GilvarG, C. (1975b). Specialised peptide transport system in Escherichia coli. Journal of Bacteriology 122, I 200-1 207.

Barak, Z., Sarid, S. \& Katchalski, E. (I973). Inhibition of protein biosynthesis in Escherichia coli B by tri-L-ornithine. European Journal of Biochemistry 34, 317-324.

CASCIERI, T. \& Mallette, M. F. (1974). New method for study of peptide transport in bacteria. Applied Microbiology 27, 457-463.

COWELL, J. L. (1974). Energetics of glycylglycine transport in Escherichia coli. Journal of Bacteriology 120, 139-146.

Davis, B. D. \& Mingioli, E. S. (1950). Mutants of Escherichia coli requiring methionine or vitamin $\mathrm{B}_{12}$. Journal of Bacteriology 60, 1 7-28.

GilvARG, C. \& LEVIN, Y. (1972). Response of Escherichia coli to ornithyl peptides. Journal of Biological Chemistry 247, 543-549.

Hayman, S., Gatmaitan, J. S. \& Patterson, E. K. (1974). The relationship of extrinsic and intrinsic metal ions to the specificity of a dipeptidase from Escherichia coli в. Biochemistry, New York 13, 4486-4494.

Kessel, D. \& LuBIN, M. (1963). On the distinction between peptidase activity and peptide transport. Biochimica et biophysica acta 71, 656-663.

Lazdunski, C., Basuttil, J. \& Lazdunski, A. (1975). Purification and properties of a periplasmic aminoendopeptidase from Escherichia coli. European Journal of Biochemistry 6o, 363-369.

NAIDER, F. \& BECKER, J. M. (1975). Multiplicity of oligopeptide transport systems in Escherichia coli. Journal of Bacteriology 122, I 208-1 215.

Patterson, E. K., Gatmaitan, J. S. \& Hayman, S. (1975). The effects of $\mathrm{Mn}^{2+}$ and $\mathrm{Co}^{2+}$ on the activities of a zinc metallodipeptidase from a mouse ascites tumor. Biochemistry, New York 14, 426I-4266.

PAYNE, J. W. (1968). Oligopeptide transport in Escherichia coli: specificity with respect to side chain and distinction from dipeptide transport. Journal of Biological Chemistry 243, 3395-3403.

PAYNE, J. W. (1972a). The characterization of dipeptidases from Escherichia coli. Journal of General Microbiology 71, 267-279.

PAYNE, J. W. (1972 b). Variations in the peptidase activities of Escherichia coli in response to environmental changes. Journal of General Microbiology 71, 28I-29I.

PAYNE, J. W. (1974). Peptide transport in Escherichia coli: permease specificity towards terminal amino group substituents. Journal of General Microbiology 8o, 269-276.

PaYNe, J. W. (1975). Peptide transport in microorganisms. In Peptide Transport in Protein Nutrition, pp. 283365. Edited by D. M. Matthews and J. W. Payne. Amsterdam: North Holland.

Payne, J. W. (1976). Peptides and microorganisms. Advances in Microbial Physiology 13, 55-I 13.

Payne, J. W. \& Gilvarg, C. (1971). Peptide transport. Advances in Enzymology 35, 187-244.

Putnam, S. L. \& КосH, A. L. (1975). Complications in the simplest cellular enzyme assay: lysis of Escherichia coli for the assay of $\beta$-galactosidase. Analytical Biochemistry 63,350-360.

SimmondS, S. (1970). Peptidase activity and peptide metabolism in Escherichia coli $\mathrm{K}-\mathrm{I} 2$. Biochemistry, New York 9, $\mathrm{I}-9$.

Simmonds, S. (1972). Peptidase activity and peptide metabolism. In Peptide Transport in Bacteria and Mammalian Gut, CIBA Foundation Symposium, pp. 43-53. Amsterdam: Associated Scientific Publishers.

Simmonds, S., Szeto, K. S. \& FletTerick, C. G. (1976). Soluble tri- and dipeptidases in Escherichia coli K-I 2. Biochemistry, New York 15, 26I-27I.

Sussman, A. J. \& Gilvarg, C. (1970). Peptidases in Escherichia coli K-12 capable of cleaving lysine homopeptides. Journal of Biological Chemistry 245, 651 8-6524.

Sussman, A. J. \& Gilvarg, C. (1971). Peptide transport and metabolism in bacteria. Annual Review of Biochemistry 40, 397-408. 